\title{
The place of Cyprus traditional child games in contemporary education
}

\author{
Öznur Şevket ${ }^{1, *}$, and Sadrazam Ejdan ${ }^{1, *}$ \\ ${ }^{1}$ Near East University, Faculty of Arts and Sciences, Turkish Language and Literature, Nicosia-99138, North Cyprus
}

\begin{abstract}
Since the beginning of mankind, games, as multi-purpose activities, have taken place and will continue to function as so in many fields, such as cultural transmission, recognition of traditions, education etc. Traditional games widely adapted by each society are quickly abandoned under the threat of modern technological developments and some are completely forgotton. Some of these traditional games, however, are of particular importance and still preserve their educational values. Particularly the conscious and volitional efforts put into preventing their existence will help the new generations develop contemporary skills which cannot be adapted particularly by electronic games. The aim of this study is to raise suggestions to indicate the educational values and the proper application of some of the child games with exceptional importance among the all.
\end{abstract}

\section{Introduction}

Child games are free-time activities for fun and enjoyment as well as healthy development. Games provide unique opportunities for the child to recognize itself, know the environment and for families to know their children better, which is an effective way of a child's physical, motor, social, emotional, intellectual and personal development [1]. Child games starting at infancy develop social-emotional skills at later ages as well as success in life. This effect can be evaluated both in psyhcological and sociological dimensions.

Games affect a child's psychological development. During the primary stage of the development of psychoanalytic theory, Freud referred to child games phenomenon in order to define and specify the basic characteristics of psychic functions in adult life. Direct observation of children in games does not only provide analytical information about the functions of games, but also the early childhood experiences in psychological development. Freud emphasized the importance of games in a child's life when it starts to utter words and organize thoughts. Children experience satisfaction when they play the similar or discover new games. "Game" is not limited by the meaning of words or the consistency of sentences. Games, [2] are assumed as the discharge of instinctive drives and a mode of an experience of quite an impression on children.

Children adapt new experiences through games and develop their physical, cognitive, affective, linguistic, and social skills. However, these games are not promised to develop such skills [3]. On the contrary, participating in games attracts children and makes them happy. As volunteer individuals in games at the beginning, children develop flexible and creative thinking and problem solving skills, become self-confident, and get ready to adapt living conditions. Experiencing the realities of life starts with learning the principles of games. Games as educational and instinctive experiences help children develop skills they need in their adulthood [4].

Children, starting in their immediate environment, start to socialize through games. They start to recognize the culture of the society they belong to and become a part of it. Games have a big role in adapting cultural values [5]. In this respect, through games, individuals acquire basic knowledge, skills, and behaviors which are essential for social sustainability.

The "Agreement on Preserving Intangible Cultural Heritage" adapted by UNESCO in 2003 defines and includes child games in cultural heritage. However, parallel to the economical, political, cultural, and social changes, child culture, games, and toys are subjected to radical changes and while specifying the living environment, traditional games are rapidly ignored and this a loss for the children. Therefore, emphasizing the functions of traditionl child games complied from Cyprus folk culture is of utmost importance.

\footnotetext{
*Corresponding authors: sevket.oznur@,neu.edu.tr; ejdan.sadrazam@gmail.com
} 
Today's industrialization, urbanization, technological developments, capitalism, consumption culture, and the globalization of all these issues caused a change in child image and toy culture. While traditional games are ignored, games and toy sectors have emerged as an industry. In other words, children are left to live in the culture created by adults.

According to Piaget [6], children form their social world as long as they interprete, follow and make use of knowledge. Thus, games help children adapt the culture of the society and cognitive development. This proccess, named "socialization", includes a child's assessing his/her drives, getting ready for prospective roles, and building a world of meanings/values. The skill of accomodating oneself, which is the key to life, makes one the member of that culture. This, as a result, constructs a sound relationship between socio-economic organizations and socialization of the child. At this stage, the child is not passive. Children try to understand the adult world and begin to build their peers' world and culture. Today, the traditional line beween adult and child world is not apparent. This is undoubtedly, because children can share the same information with adults through the internet and other communication tools. It can be observed that interest in disapproved adult styles by children, such as alcoholism, drug addiction, interest in sex, and crime begin to interfere in child life.

Postman [7] argues that games, used to be witnessd in streets in the past, are not interesting for children any longer and today's generations do not know much about these games. Even more, the concept of "child games" is completely out of our minds. "Child games" do not mean much for children or adults. This makes the child and adult dress and behave in similar ways and, due to academic presseure, forces them to become members of the consuming society from the quickest way. That is to say, children are not in streets or in the nature, but in front of computers playing the same computer games with their parents and adults forgetting child games and sharing the same environment and language with them. As a result, the child becomes fast living, fast consuming, ambitious, selfish, matreialist, and fond of self-comfort, with undeveloped physical skills and mutual relationships, and unaware of altruism.

The companies of the Neo-liberal era, observing these changes closely with profit in mind, began to address to children with new marketting techniques. At present, the digital game market, with one billion players, as exceeded 70 billion dollars. At the age of 5-6, children start using the digital world [8]. The so-called "needs" are introduced through advertisments, which is a condition for capitalism to reproduct itself. The system rejects conscious people who may oppose to needs. Therefore, children are the appropriate sources for capitalism. Game and toys are not merely merchandise, but a means to make children adapt consumption culture through game culture. When digital- game culture is considered, it can be observed that, it is supported by various marketing techniques and industries raised on these games produce merchandise addressing children to make them consumers. The games are speculated on violence, wars, and dominance. Inclination to violence among children and the youngsters is closely related to the frequency and duration of the game [9].There is a direct connection between depression and problematic computer use and loneliness and weak performance [10]. Influenced by the game, a child starts to exhibit violence as a usual behavior in real life. Games are not played in real places, but in imaginative environments. Face-to-face, sincere, warm relationships are placed with avatars created in independent environments free from societal identity. As stated by Bourdieu, once one joins in the game, he/she finds it worth playing and this indicates DOXA, the settled order of the area is approved and adapted. Behaviors determining how to reach the end, help individuals form common proximity, called "habitus" by Bourdieu [11]. Regardless of national differences, Habitus has influenced all children similarly all around the world forming a common dimension. In other words, these processes aim to raise child users, but not creators. The international circulation of heroes animated by Hollywood is making children American fans in terms of culture industry. In traditional child games, competition and display of power are of primary importance. Heavy population, urbanization, traffic, increase in crime rates, and lack of natural game areas make children stay indoors. This naturally put an end to free speculation which is the most crucial factor in creativity in games and of toys.

The biggest problem in today's toys is that they became more than an object for children due to the markets and popular culture free from children. Today, before anybody else, entrepreneurs, advertisers, and salesmen are more interested in toys. Children playing with electronic toys find it difficult to socialize, are exposed to radiation, and experience a slow development in psycho-motor and cognitive skills [12]. Imaginative games cause social insulation. Children may account eating, sleeping, going to school, in short basic responsibilities as obstacles between themselves and the computer and may delay or forget to carry out their tasks [13]. Digital games slow down reading habits as well as pleasure. Children, a part of today's consuming culture, have a different perception of happiness. Children brought up in physical, emotional, and social depreviation believe that they can compensate happiness through consumption. Under all circumstances, traditional games have become more popular because they are mostly played in groups based on collaboration with real partners, which can balance false identities. Games are usually played in open areas and help physical development. They consolidate interaction and forming friendships. They are the ground for sharing, common activities, team- work, leadership, and social communication. Children brought up with traditional games without the transfer of written culture rather than from the internet are more natural and creative, they have more respect to others, and avoid violence. 


\subsection{Aim of the Study}

This study aimed to investigate the quality of Cyprus traditional child games and their functions in adapting skills in life. The games compiled were taken up in terms of skills prescribed in Primary education programs, skills aimed to in life such as, communication, problem solving, decision making, self-management, collaboration and forming teams, management of emotions, entertainment and leadership.

\section{Methodology}

A Culture Analysis Design was conducted in this research to specify child games and their functions in adapting skills. Besides individual perceptions and behaviour, Culture Analysis Design focuses on specifying and analysing cultural elements such as social structure, functions, and values [14]. The data were collected through document analysis, one of qualitative methods. Qualitative methods include several methods and sources are the most effective ways in which written or verbal human experiences or records are examined to provide data for he researcher [15]. The document analysis form includes dimensions related to the name of the game, where and with whom it is played, the number of players, the age range of the players, aim of the game, and selection the "IT". A descriptive analysis method was conducted in the analysis of the data. The analyses were grouped and examined under the theme of "child games". Evaluations related to the role of child gmes in developing life skills were carried out independently by the researchers and an expert for consistency.

\section{Findings and interpretation}

Four different "child games" were taken up to examine their functions in acquiring life skills.

Table 1. The main development areas supported by traditionl games

\begin{tabular}{|c|c|c|c|}
\hline & Type of development & Are & Characteristics \\
\hline A & Cognitive & $\begin{array}{l}\text { Personality, language development } \\
\text { raising ideas, creativity, discovering }\end{array}$ & $\begin{array}{l}\text { Understanding others, being } \\
\text { understood, body language etc. }\end{array}$ \\
\hline B & Physical & rudeness/kindness & $\begin{array}{l}\text { Using the area, distance, } \\
\text { speed, releasing energy etc. }\end{array}$ \\
\hline $\mathrm{C}$ & Emotional & $\begin{array}{l}\text { Self-esteem, enjoying, improving } \\
\text { power of imagination }\end{array}$ & $\begin{array}{l}\text { Conformance, feeling of } \\
\text { happiness, freedom }\end{array}$ \\
\hline D & Social & $\begin{array}{l}\text { Participation, sharing, waiting fo } \\
\text { one's turn rivalry, interaction, } \\
\text { collaboration, coordination } \\
\text { Empathy, communication, } \\
\text { leadership etc. }\end{array}$ & $\begin{array}{l}\text { Caring about others' feelings, } \\
\text { demands, intentions etc. }\end{array}$ \\
\hline
\end{tabular}

\section{Andrez}

This is a game of care and thought played by two grown-up children. The game goes as; the players draw two interbedded squares on the ground or on a flat surface and crossed by four lines going across the angles and medial lines. The players have six stones in different colors and place them on the drawing randomly. This is called "placing" (konmak). Then it is time to make the "move" in which the players try to carry the stones onto the intersection points. _ The one who does it first, shouts out "andrez" and is the winner of the game. The game can be played by two players with nine stones as well. Each try to occupy the "tripple door" first. The player who puts three stones together, has the right to take one stone from the other player. The one who has five stones left, is the winner of the game [16].

Skills acquired in this game:

- Physical skills: Geometrical drawing though three-dimensional thoughts improves and strengthens the child's area concept. Using hands and feet develops fine-motor skills such as grasping, holding, writing, drawing, cutting etc. 
- Psychological and emotional skills: Children belive that entertainment, as studying, is a natural need and pick peers to play in harmony. They are by themselves when solving problems and start to understand what freedom means. Too much pressure on a child causes loss of self-confidence and develops a timid and worried personality. The rules of games help the child to repect to peers and be a disciplined individual. The child also has the opportunity to know his/her feelings as well as the peers's feelings by observing and questionning.

- He/She becomes aware of how mutual and self feelings affect each other. He/She learns how to control anger and in case of failure of control, he/she knows that the game can not be played.

- Social skills: This game helps the child make decisions and experience the results. He/She learns how to protect his/her rights and specifies his/her status in the society.

-Intellectual skills: The child decides on single moves which indicates that he/she is in touch with the competitor. This gives the child time to calculate both verbal communication and the kind of moves likely and develop emphathy skills. The child has to exhibit skills in taking quick decisions to guess the competitor's unexpected moves and strategies and in the flow of the game, think and change strategies. Obeying the rules of the game is important in terms of developing self-management skills. Children are very careful about applying the rules of the game. In this respect, the game "Andrez" has a crucial role in adapting skills in obeying social rules.

\subsection{Alaydan - Malaydan}

This game is played by boys and girls together, as two groups. Hand-in-hand, the children make two rows facing each other. The first group starts to speak out. Meanwhile, the whole group moves three steps to the left and three steps to the right or to the front or back in rhythmic movements as if dancing. The first group sings:

With a quick movement, each group tries to pull a member of the other to their side. If they fail, then a member of their group is transferred to the other. Any group with only one player left, is the loser [16].

Skills acquired in this game:

- Physical skills: This game improves and strengthens field conept. It helps the child learn where to play each game. It also helps the development of gross motor control in standing and movement, controlling the head, sitting, crawling, walking, running, rolling, jumping, and balance positions etc. which are followed by the development of power, speed, endurance, and forming skills.

- Psychological and emotional skills: Children believe that, as studying, entertainment is a natural need and they pick peers and suitable places to play in harmony Following the instructions of the game, helps the players be disciplined and respect peers.

- Social skills: Working collaboratively in this game helps children develop their skills in team-work. They believe that they lose or win together as a team, which makes them focus on the need for collaborative work. Participating in making decisions and specifying targets help develop democracy culture. Their roles in making decisions and sharing the same aims strengthens social relationships, in which the children establish an environment away from their families.

- Intellectual skills: Children acquire skills in tongue-twisters as well as comunicating through body-language. This game helps children develop linguistic and communication skills in listening to peers, expresseing feelings and thoughts verbally, using body-language, discussing which group to eliminate and persuading peers when necessary. The Leader, on the other hand, should exhibit skills in leading his group and act upon the capacity and power of the component team, knowing them well, making quick sound decisions in case of unexpected attacks, and examining their strategies. When the child notices differences in speed and power, he/she also notices weaknesses and strengths of his/her peers. This is an important point in one's noticing other individuals' strengths and weaknesses.

\subsection{Beşdaş}

This is a game played by boys and girls. It is big fun, but requires attention. It is played between two or a group of players. They toss a coin (heads or tails) for the one to start first. The first to play has five small, round stones and throws them on the ground. The picks one of them and throws it into the air. By the time the stone falls down, he picks another from the ground and tries to catch the one before it is down. This goes on until he picks all the stones from the fround. After picking all the stones, and restarts the game and picks the stones from the ground in 2 s. In the third throw, he he picks three and then one stone from the ground. In the fourth throw, he has to pick four stones. What is important in this game is that the player has to pick the stones before the one thrown into the air falls. If he fails to catch it, then he loses the game.

In the second stage of the game, a bridge is formed with the left thumb and first finger (index finger) on the ground. The stones are in the right hand and are pushed through the bridge from the back to the front. As in the firrst part of the game, the stones are pushed one by one, then in three-one, and finaly in four. In case of failure in pushing the stones as a rule before the one in the air falls down, then the game is lost. 
In the third and last part of the game, the player has all the stones in one hand, one held between the thumb and first finger of the right hand and the others in the palm. The single stone is thrown into the air and the other four are left on the ground. By the time the stone is down, the player has to pick all four other stones from the ground. Failure means the loss of the game.

Skills acquired in this game;

- Physical skills: This game is based on using the are in the most effective way. Therefore, it helps improving area concept. It is also extremely effective on the skill of prcticising fine motor skills because hands and feet, catching and holding and the coordination of eyes and hand function at the same time.

- Psychological and emotional skills: The child assumes that entertainment is a natural need as working and specifies proper places and individuals for enjoyment. He has a good time with peers. Sharing satisfaction makes him happy and self-confident. He is by himself while sorting out problems and becomes disciplined and respectful towards peer. If he wants to be liked by others, he has to follow the rules of the game, whichis most crucial principle to take part in a game. In other words, the child, willing to play the game, learns while playing that he has to respond to the rules of the gme. At this point, it can be said that obeying the rules of the game has a lot to do with adapting skills in complying with the rules of the society. The child also observes how peers' behaviors affect his feelings and tries to find ways to control anger. He knows that, if he fails to control anger at this stage, will keep him out of the game.

- Social skills: The child learns how to defend his and others' rights and establishes an environment of his own away from the familiy.

- Intellectual skills: In terms of communication, it is observed that the players use their verbal and bodylanguage skills. Individuals participating in the game either in groups or individuals, always communicate with each other. Listening to peers, expressing thoughts and feelings verbally and using body-language help develop the child's language and communication skills. During the game, the child watches peers' hand talents and compares with his and notices similarities and differences. He knows all objects and refers to them while playng the game, which improves his skills in comaring.

\subsection{Ayakdaşı}

This is a game played both by boys and girls. In some areas it is also known as "bir ayak" (single foot). A rectangular is drwan on a flat surface and is divided into six equal squares. On one side of the rectangular, a hole is dug In the middle. This is the place where the stone is thrown. The one who throws the stone to the very near of the hole is the winner. This game is played on single leg and with a flat stone. After the fourth try, the player stops to rest. The player tries to push the stone to the next square with one kick. If the stone is not in the square, but on the line, that player is the loser. In the second part, the stone is put in the second and in the third in the third square. Thaty is to say, the stone is put through every square. The one with no failure, plays the game the second time. The winner is the one with no failure. The game is played between two or a couple of players. Every successful turn of the game is a negative point for the opposing players. The player(s) with no negative points is (are) the winner(s) [16].

Skills acquired in this game;

- Physical skills: This game helps the child know geometrical shapes,and develops and strengthens area perception. It also contributes to the development of gross motor skills such as the position and movement of the body, controlling the head, sitting position, crawling, standing position, walking, running, rolling, jumping, and keeping balance as well as power, speed, flexibility, endurance and coordination skills.

- Psychological and emotional skills: The child assumes that entertainment is a natural need as working and specifies suitable places and peers to entertain himself. He notices the connection between developing physical abilities and emotional satisfaction. Complying with the rules of the game, helps him become respectful towards peers and be disciplined.. in addition, the child becomes aware of his feeling while playing the game. Similarly, he observes others' feelings by watching, hearing, and questionning. He realizes how his feelings affect his body and the effect of his feelings on others.

- Social skills: The child considers others' rights and learns to fight for his rights. He establishes his own environment away from home.

Intellectual skills: Either played individually or in groups, the players always interact with rch other. Listening to peers, expressing thoughts and feelings verbally, using body-language contribute to the development of the chld's language and communication skills. The basics in playing child games is to follow the rules. That is, the child has to obey the rules of the game if he is willing to join the game and play with peers. Games play a great role in terms of acquiring skills to adapt social rules. The child observes the different skills of others in jumping and keeping the balance, which helps him notice his weaknesses and strengths. 


\section{Conclusion and suggestions}

Game is freedom for a child and it is a drive that arouses all talents [17]. Games are not merely to occupy free time. The characteristics of a game have a great role in a child's learning and developing skills. While in games, the child learns to communicate, share, work, and solve problems together. He experiences social rules through natural ways and develops his skills. Children in primary education need to acquire physical skills, adapt to the ones at his age, learn current concepts necessary in daily life, and develop moral values etc [18].

The indiations of this study are that traditional child games among children in primary education have a big role on the development of physical, psychological, social, and intellectual skills such as self-management, language-communication, problem solving, decison making, leadership, entertainment, coordination and team formation. Furthermore, all the games mentioed above are free of charge compared to today's games and toys.

In order to support child development and transfer traditional child games to future generations, there should be "public- culture classes" consisting child games as "teaching tools" and integrating traditional games into Physical Education classes to support physical development. As Pam Javis (2013) stated, the positive connection between games and development is a crucial factor, therefore, child games should be introduced in school programs after strict observation in terms of safety of traditional games and precautions [19]. Prior to designing programs, educational aims, order and duration of activities and materials should be well specified and both teachers and parents should be well informed about games. It is believed that, traditional child games will open the way to children to know and transfer abstract cultural heritage, enable them to adapt living skills, and, to a great extent, will lessen the harmful effects of computer games.

\section{References}

1. E. Duralp, N. Aral, Oyunun Gelişimi ve Türleri, Okul Öncesi Eğitimde Oyun (A.B. Aksoy,ed.) İçerisinde. Ankara: Hedef, 32, (2017)

2. S. Freud, Beyond The Pleasure Principle. S.E.18. 7-64. Çevrimiçi: http://www.openschooleast.org/wpcontent/uploads/2015/11/sigmund-freud-BPP.pdf, 24/02/2019, 17, (1920)

3. N. Özdemir, Türk Çocuk Oyunları. Ankara: Akçağ Yayınları,343, (2006)

4. M. Sevinç, Erken Çocukluk Gelişimi ve Eğitiminde Oyun, İstanbul: Morpa Yayınları, 54, (2004)

5. 5.T. Gürkan, E. Gökçe, Türkiye'de ve Çeşitli Ülkelerde IIlköğretim, Siyasal Kitabevi, 3, (1999)

6. J. Piaget, The Moral Judgement of the Child,London: Routledge\&Keagen Paul, (1932)

7. N. Postman, Çocukluğun Yok Oluşu. Ankara: İmge, (1995)

8. G.Yücel, Ş. Şan, Dijital Oyunlarda bağımlılık ve Şiddet: Blue Whale Oyunu Üzerine Bir Inceleme, Online Academic Journal of Information Technology. 9, 32, 88-100, (2018).

9. S.Eroğlu, Saldırganlık Davranışının Boyutları ve işkili Olduğu Faktörler: Lise ve Üniversite Öğrencileri Üzerine Karşılaştırmalı Bir Çalışma.(Yayınlanmamış Doktora Tezi). Konya:Selçuk Üniversitesi Sosyal Bilimler Enstitüsü, 59 (2009).

10. B,Bolışık G, Karayağız, Çocuk ve Gençlerde Internet Kullanımı, TAF Preventive Medicine Bulletin, 8, 5, S.445-450, (2009)

11. P. Bourdieu, L.J.D. Wacquant, Düşünümsel Bir Antropoloji için Cevaplar. İstanbul: İletişim, 82,(2003).

12. K. İnan, Çocuğun Örselenen Dünyası. Ankara: Sobil Yayınları, 134-137, (2007)

13. A. Durmuş, Eyvah! Çocuğum Bilgisayar Kullanıyor. İstanbul: Nesil Yayınları, 81,(2007).

14. A. Yıldırım, H. Şimşek, Sosyal Bilimlerde Nitel Araştırma Yöntemleri, Ankara: Seçkin Yayıncılık, 70, (2005)

15. P,Keith, Introduction to Social Research-Quantitative and Qualitative Approaches, London: Sage, 165, (2005)

16. O. Yorgancioğlu, Kıbrıs Türk Çocuk Oyunları, Lefkoşa:Ada, (1997)

17. A. Yörükoğlu, Çocuk Ruh Sağlı̆̆l, İstanbul: Özgür Yayınları, 150, (1989)

18. H. Bacanlı, Eğitim Psikolojisi. Ankara: Pegem A Yayıncılık, 48, (2007)

19. A,Brock, S,Dodds, S. et.al.. Perspectives on Play: Learning For Life. New York: Pearson, (2013) 